\title{
Vera Brittain's Testaments of Labor, Work, and Action
}

\author{
Austin Riede
}

And the Gods of the Copybook Headings said:

"If you don't work, you die."

--Rudyard Kipling,

"The Gods of the Copybook Headings" (1919)

Vera Brittain's Testament of Youth (1933), a memoir of her childhood and experience as a Voluntary Aid Detachment (VAD) nurse in the First World War, offers valuable insight into the ways in which the war changed the conditions, representations, and political implications of English women's labor. Throughout the memoir's three sections, Brittain retrospectively explores what her own labor meant, both in personally coming to terms with her exceptional losses (her fiancé, brother, and two close friends were killed in the war) and with women's larger political and cultural position in England. Despite its centrality to Testament of Youth, however, few scholars have engaged with Brittain's representations of labor. In this essay, I will argue that Testament of Youth importantly exemplifies the three categories of labor, work, and action Hannah Arendt would later define in The Human Condition (1958), specifically illuminating how they applied to English women's experiences in the years surrounding the war. Furthermore, Brittain's memoir engages such

Austin Riede is a Ph.D. candidate in the department of English at the University of Illinois at UrbanaChampaign. His research interests include British and European modernism, interwar culture, the avant-garde, and science fiction. He is currently writing his dissertation, which draws on the work of Michel Foucault and Hannah Arendt, among others, to analyze how structures of psychiatric, social and state power in England were transformed by the First World War, and how these transformations impacted English Modernism and interwar culture. 
categories in a more sophisticated, if indirect and ambivalent manner, than has yet been acknowledged. Testament of Youth demonstrates how, through constantly attempting to distill a philosophy of labor that would sustain her through the war, Brittain transforms from a prewar provincial "pretty-pretty" (116), being groomed for marriage and constrained by an Edwardian bourgeois community of constant surveillance, to a fiercely independent political activist. What is most remarkable about this metamorphosis is the extent to which she presents her personal history of trauma and recovery as mapped onto national/international political narratives, and what her commitment to education, voluntary nursing, and ultimately the League of Nations, suggests about the modern connections among the English subject, state power, and individuality.

Testament of Youth was published in 1933, eight years after the period it documents ended. By 1925, Brittain felt that she was on her way to a new life with new friends, a family, and a career. With few remaining acquaintances to share in the memory of a life that ended for her with the war, she felt the need to revisit a past that was increasingly cut off from the comforts and relative fulfillment of middle age. She writes in the foreword that she had wanted "with a growing sense of urgency" to write about her war experience for nearly a decade (11). After making several aborted attempts at fictionalizing her story or adapting her diaries, she decided only a memoir would accurately express the lived changes she wanted to convey. She wrote Testament of Youth largely by re-visiting and connecting disparate entries from past diaries and letters to and from her family and friends. She writes:

I wanted to give $[. .$.$] an impression of the changes which that$ period brought about in the minds and lives of very different groups of individuals belonging to the large section of middleclass society from which my own family comes.

Only, I felt, by some such attempt to write history in terms of personal life could I rescue something that might be of value, some element of truth and hope and usefulness, from the smashing up of my own youth by the war. (11)

This attempt to salvage some kind of use value from the war is a recurring theme in the memoir. Brittain wants to demonstrate that, even if what she has written "constitutes, in effect, the indictment of a civilisation," the war, and the labor and lives that were sacrificed for it, will still have use-value for that indicted civilization if it will learn from its past (12). The terms of the memoir's ambivalence toward the war are thus clearly set. As I will demonstrate, ambivalence colors nearly every aspect of Brittain's engagement with work, labor, and action.

Most criticism of Testament of Youth has focused on Brittain's feminism and/or her coming to terms with her losses through the process of writing. Accounts of Brittain's feminism generally focus on its apparent paradoxes or inconsistencies, from Susan Leonardi's critique of Brittain's willed ignorance of Winifred Holtby's lesbian desire and her frantic imposition of heteronormativity on both her best friend and her text, to Meg Albrinck's more nuanced reading of how Brittain needed to 
inhabit (in de Certeauvian terms) and render habitable the off-limits space of war experience to present her feminist perspective on the war. Although the arena of labor has not been a focal point for understanding how Brittain constituted her feminism, Brittain significantly cites Olive Schreiner's Woman and Labour as one of the formative texts of her feminism. She writes that she "can still tingle with [...] excitement" on reading the passage that begins "We take all labour for our province!" (41, emphasis in original). This passage inspires her as she repeatedly confronts her father's injunctions that she should prepare for marriage and forget her ideas of going to Oxford. Moreover, it is only because Roland Leighton, her future fiancé and fellow Schreiner devotee, tells her that he has been a feminist ever since he realized that his mother's income from writing novels helped pay for his education, that she becomes really interested in him (84).

Brittain's philosophical and physical engagements with labor shape her mourning as much as they shape her feminism. Much scholarship has focused on the nexus of autobiographical form and trauma, asserting that Brittain's book grapples primarily with the subjectivity of the dead. Victoria Stewart posits, for example, that Brittain's book “testif[ies] on behalf of" her dead companions (28). In a similar, if more psychoanalytic, reading Richard Badenhausen reads the text as a kind of talking cure for trauma. Badenhausen posits that through her memoir's method of pastiche, which creates a (male) community of the dead amongst whom Brittain can converse, she is able to escape a state of Freudian melancholia and finally "break faith with the dead" enough to move on (247). By ignoring Brittain's presentation of her relationship to her labor as a volunteer nurse behind the lines during the war, her work at Oxford as a student and writer, and her postwar action as a political speaker for the League of Nations, these readings risk reducing her to a mere mourner. I argue that the community Brittain needed she found for herself, not in imagined communications with dead men, as is commonly assumed, but by first cultivating her own subjectivity, a radical move for a provincial young woman of her generation, and then moving, in Arendtean terms, from the unrewarding and thoughtless condition of labor, through the self-making condition of work, and finally to a relative freedom in action, that inter-human, communal condition that creates mutual recognition and progress.

Far from passive pastiche, Brittain's personally invested postwar action during the early twenties presents an alternative to Britain's postwar paralytic conversation among the fragments of a ruined civilization and its mania for creating countless but futile memorials to the war's dead while exhibiting veiled hostility for its survivors. While the cosmopolitanism of much postwar modernism (e.g., Pound's The Cantos and Eliot's The Waste Land) self-consciously and almost dissemblingly seems to work, so it can self-consciously fail, to make the fragments of a lost European order cohere, or, to find cultural identity in England's deep, mythic history (as in Mary Butts' Taverner novels, and Virginia Woolf's later fiction) Brittain's internationalist action is dedicated to forging a coherent community of nations.[i]

Brittain moves through these various stages of social engagement alongside acceleration in the transformation of traditional state power into biopower, according to Michel Foucault, a process underway since the eighteenth century (Reid 127); 
if Brittain's internationalism never quite breaks the ideological boundaries of this modern paradigm of state power, it at least pushes up against them. Giorgio Agamben points to the First World War as the period in which, through the exercise of the "state of exception" across Europe, state sovereignty's basis in biopower became apparent (7). The war was a crucible for the biopolitical model of power, a crucible within which biopower was strengthened by devising what Julian Reid has defined as "strategies" of control over the "natural body" (129-134). Brittain's personal experiences in the war reflected the changes that the war compelled in England's biological control over its subjects: the conflict demanded a disciplinary demonstration of the sovereign's power of life or death over its subjects - the old paradigm of sovereignty elaborated by Hobbes - through direct state interventions into the biological existence of its subjects. The Defence of the Realm Act (1914), for example, granted unprecedented executive powers. The Conscription Act (1916) demanded total corporeal control of male subjects on threat of death. It also produced, however, more diffuse mechanisms to preserve its sovereignty and the life and well-being of the English "race" at the social and biological level. The aspect of this biopoliticization of state power that is most important in regards to Brittain's development and recovery, however, is that, as Foucault explains, biopower relies on "techniques oriented toward individuals and intended to rule them in a continuous and permanent way" (Power 300). Through the self-care encouraged by the postwar environment, Brittain finally accepts what had been to her the unacceptable conditions of her subjectivity and moves beyond her justified but futile anger against the state and culture for which she had sacrificed everything. She becomes, once again, an engaged state subject and an object of direct power, doing what she is told. This subjectification, which she recognizes as inhering in not only herself, but also her entire culture, marked the end of an age.

\section{i. Work and Subjectivity}

Brittain's initial description of her late Victorian/Edwardian provincial childhood is unsurprising: she describes her childhood home as representative of "all that was essentially middle-class in that Edwardian decade" (23). She was naïve and sheltered. She was, as far as she knew, the only person interested in the larger world outside her provincial town, and evidently terrified by some unnameable presence lurking in the apparent safety of dreary Buxton. Her numerous childhood terrors "of thunder, of sunsets, of the full moon, of the dark, of standing under railway arches or crossing bridges over noisy streams, of the end of the world and of the devil waiting to catch me round the corner" (24) seem directly connected to the random "tempestuous explosion[s]" (23) from her father and the patriarchal power structure that pervaded her community and acted as a constant surveillance mechanism over her subjectivity and her body. One source of these fears is distinctly her failure to appropriately recognize male privilege: when, "at the age of five or six" a nursemaid heard her call her brother Edward a "'Little fool!"” the maid told her "'There, you've done it! Now you'll go to hell!'" (24). But the fears she recalls are mostly not of substantial things, or of frightening acts; she fears the images that would have saturated, like patriarchal power, her childhood. The 
constraints on her subjectivity as a provincial Edwardian girl are omnipresent, invisible in their ubiquity, inscribed in everything around her and even directly onto her body. Reflecting on the freedom of the interwar years, she writes "I am seized with an angry resentment against the conventions of twenty years ago, which wrapped up my comely adolescent body in woolen combinations, black cashmere stockings, 'liberty' bodice, dark stockinette knickers, flannel petticoat [etc.]" (34). With the psychological insight she has gleaned in the postwar years, and which she continually draws on as an article of faith, Brittain is able to look back at her childhood and teenage years and see how the omnipresent and crushing structure of paternalist control inhibited her subjective development. Sartorial constraints function, at the level of the body, to perpetuate the larger constraints and surveillance with which Brittain must struggle.

The Edwardian community and family structure was devised to prevent the subject from recognizing and constituting itself through the personal work that, in engaging the world, constitutes the self. Recalling her feelings after moving in with Winifred Holtby in 1920, she writes:

There had been no privacy in Victorian or Edwardian childhood, and from the age of thirteen to twenty-seven, I seemed to have lived in public. At school I had gone to bed and got up in dormitories $[\ldots]$, read and worked in the company of others; nothing perhaps is still so oppressive in traditional boarding school life as the inability of a boy or girl ever to be quite alone. [...] No member of that pre-war provincial "set" could hope to live to herself even if adult, and local and family searchlights had played continuously upon the dearest hopes, the most intimate relationships of every young person. (546-7)

This reflection is possible because conditions changed after the war. Brittain's description presents a tension in that this surveillance is "still so oppressive" and that it was the particular burden of the "pre-war provincial set." The deep moral structures that had kept surveillance over the early lives of the bourgeoisie had been attenuated by the experience of war and generational alienation. The war thus colors Brittain's description of Victorian/Edwardian childhood - the communal vigilance of the family structure scrutinizes the subject with "searchlights" — metaphorically indicating the war "just beneath the surface of peace" that Foucault suggested may be the foundation of power ("Society" 47).

Likewise, even in her courting with Roland, the two hardly ever had any time to themselves, as "the whole series of complicated relationships leading from acquaintance to engagement had to be conducted in public or not at all" (120). Such a carceral social structure insures the conformity that was necessary for the war to last as it did, and inexorable scrutiny prevented the discussion of what Ford Madox Ford, in his pre-war ethnography of England, called "things," i.e., politics, religion, sexuality, etc. (England 312). Not being able openly to discuss any of these things inhibits the formation of individual, self-analytic subjectivity. Even Brittain's youthful aspirations, such as "to extend love, to promote thought, [...] 
to combat indifference, to inspire activity" and "to know everything of something and something of everything," forged in this provincial obscurity, are, as she recognizes, so vague as to be hollow clichés (43).

Furthermore, this early training in conformity impels a universal acceptance of the war's worthiness and an inability to question, publicly or privately, its use value. Throughout her growth, this stays with Brittain, metamorphically, and gives her later anti-war sentiment a strange tension with what she always wants to believe - that there is yet some redeemable glory in war, or in the sacrifices that she and her friends made for it. Though disillusioned, she still asserts the value of her sacrifice. For instance, she affirms that "it had concrete results in stupendous patience, in superhuman endurance, in the constant re-affirmation of incredible courage" (370). She is always ambiguous about how these results should be valued, given their concreteness but also their having been for a wrong cause. Similarly, her Edwardian upbringing still marks the politically activist journalist and novelist of the twenties and thirties; when looking for an apt quotation, Longfellow "will insist upon ousting A.E. Housman and Siegfried Sassoon" (26).

Brittain's desire to go to Oxford, an idiosyncrasy frowned upon as much by her community as by her parents, was an overt rebellion and insistence on her individuality that was both psychological and political. The social wrong Brittain commits in wanting to be a student is to demonstrate interest in her self, in who she might be, and, what she might, independently, do. In Arendtean terms, this first section of the memoir documents Brittain's overwhelming desire for work, to take part in the process of shaping the artificial, human made world (Arendt 36), and thereby to shape her own subjectivity and retrieve from patriarchal power and make use of "the time that she [was] not qualified to use" (Brittain 51). Although she already has clear ideas about the kind of social life she wants to have, Brittain is clearly here concerned first and foremost with that philosophical essential that Foucault describes as "the care of the self" (Foucault Sexuality). The ancient Greek ideal Foucault describes is that the subject should relate him or herself to him or herself as subject, a self-reflection that ideally results in a state in which "not only is one satisfied with what one is and accepting of one's limits, but one 'pleases oneself.' [...] It is defined by the fact of not being caused by anything that is independent of ourselves and therefore escapes our control. It arises out of ourselves and within ourselves" (Foucault Sexuality 66). Although Brittain strives after this cultivation of self in her first year at Oxford, it will not be until she returns, after the war, that she will recognize that, to some extent, in aspiring after the work of a student, she has traded in the fetters of one set of social restrictions and regulations for another. The cultivated circles of the educated she once aspired after are not, necessarily, cultivated individual selves as much as representative of a conformist culture of cultivation.

Notwithstanding, Brittain's achievement in winning a scholarship at Somerville is considerable, but after the tremendous difficulty of arriving at a place in which she might attend to her own subjectivity unimpaired by the constant scrutiny of provincial middle-class expectations, the demands of the larger national community rear up. She is almost immediately overwhelmed by the conflict between her desire to stay at Oxford and what she perceives as the need to join the war effort. 
Both her lover and her brother having already signed up compound this need. She desires to remain close to these progressive young men who have, thus far, stood with her in her determination to develop and look to the independent subjectivity they have valued. Thus torn between "learning" or "life," and interrupted in her struggle toward independence, Brittain spends a period of philosophical stagnation unable to commit to either, "riding [her] bicycle about the hills and dales, feverishly inventing analogies and distinctions between life and death, soul and intellect, spirit and immortality" (138). When she can bear this no longer, she revealingly writes to Roland Leighton:

I remember once at the beginning of the War [...] you described college as 'a secluded life of scholastic vegetation.' That is just what it is. It is, for me at least, too soft a job.... I want physical endurance; I should welcome the most wearying kinds of bodily toil. (140)

Brittain thus flies to labor in the face of the realization that the putative philosophical claims of civilization mask civilization's emptiness, at best, or mendacious, murderous greed, at worst. Such realizations characterize much of the literature of modernism. Brittain is consistently torn in this memoir between her idealistic belief in the value of the sacrifices her generation is called on to make, and the realization that those sacrifices were unnecessary and only advanced the materialist needs of a moribund empire. The narration is almost impressionist in its vacillation between a belief in the glorious rhetoric of the early war years and moral condemnation of the war's pointlessness. Her memoir derives enormous tension from the desire to use the grand and archaic language that Paul Fussell associates with the early years of the war, and the realization that such noble pieties mask ignoble corruption (21).

The idealism of labor to which she turns in a moment of moral confusion functions much like that of Ford Madox Ford's Christopher Tietjens, in his Parade's End tetralogy (1924-8). Tietjens conceives his military service as an opportunity to give himself "clean bones" and get rid of the moral complexities the war and modern sexuality present (236). This chance to find herself, free of the ambiguity and anguish of political thought, is precisely what Brittain's mind-consuming years of intensive labor will offer-an end to ineffectual musings and the sure knowledge nursing brings that she is certainly not doing the wrong thing in the face of such destruction. The flight to hard labor, however, is necessary because of the double bind that life at Oxford during wartime, with loved ones at the front, presents. Brittain must, ideologically, support the war that she sees destroying all she cares about, but to remain in a state of reflection may challenge her entrenched Buxton beliefs too thoroughly before she has properly cultivated and invented an independent subjectivity. She turns to arduous labor, therefore, for precisely the opposite of that which she sought in the work of a student. The art of attending to the individual self is fundamentally Appollonian in its inward-focused and rational discipline. But Brittain turns, in an odd twist of the Nietzschean paradigm, to the Dionysian exaltation not of thoughtless revelry within a larger group, but of unthinking sacrifice in physically laboring for the group effort of the war. She becomes a nurse to efface, rather than to cultivate, the self. 


\section{ii. Labor and Maternity}

While fitting into the patriarchal bourgeoisie had been totally limiting, and constructing subjectivity in the arena of work was now morally unthinkable, Brittain gives herself over to the hard physical labor, and immediate personal danger, of becoming a VAD nurse, who is assigned to hospitals in Britain, Malta, and France. Because this work is so closely linked to the men by whom Brittain partially defines herself, it actually helps to preserve the patriarchal order at the level of the male body through a maternal resignation of her powers and abilities to the labor of nursing. This service corresponds to Arendt's definition of labor, both producing equilibrium in Brittain's life through the constant repetition of Sisyphean acts which must be completed for consumption (the return to active service) rather than any permanent addition to culture, and in its social construction as a maternal activity.

Arendt's justification for breaking with Marx and his followers in her distinction between work and labor lies partly in that "every European language, ancient and modern, contains two etymologically unrelated words for what we have come to think of as the same activity" (80) and in the fundamental contradiction in Marx's admission that labor had value in its reification and Marxism's promise to eradicate that valuable labor (102). For Arendt, labor is distinguished from work because it simply reproduces ephemeral products for consumption, rather than adding in some permanent way to the larger structures of the human-made world. To Arendt, the term animal laborans correctly describes the condition of the human at labor. $\mathrm{He}$ or she is merely creating the conditions for subsistence at a physical level-labor is not social, its results are not lasting, and it is the arena in which humans produce existence out of the given world rather than shaping it.

Another aspect of Arendt's philological distinction between labor and work is that in the European languages the equivalent of the word labor, and not work, is always used to mean both strenuous toil and the condition of giving birth. State power made direct use of the ideological and biological imperatives of maternity in its immensely effective wartime propaganda campaign to recruit women laborers and volunteers as well as male soldiers, using imagery of mothers and wives to impact both men and women.

Brittain's decision to be a nurse seems directly affected by this recruitment of women's maternal labor. She chose to be a nurse rather than to volunteer for other forms of labor because she wanted to get as close to the war as possible, and because she believed herself well-suited to the maternal work of nursing. Meg Albrinck has usefully demonstrated how the state's propaganda machine reinforced gender roles. Albrinck traces the emergence of a pro-natalist propaganda campaign aimed at replenishing the diminishing male stock, embodied in such books as the 1918 Women Wanted, which "puts the very catchphrase that drew women into the factories into a new context" by adding the words "for maternity!" (276). Albrinck cites one of the most iconic propaganda posters: three figures, two adults, clearly female, and one child, all representing, potentially, a mother, wife, and daughter; they stand hugging one another and wrapped in shawls at an open window gazing on the backs of a departing group of soldiers in the distance. Above them an inscription 


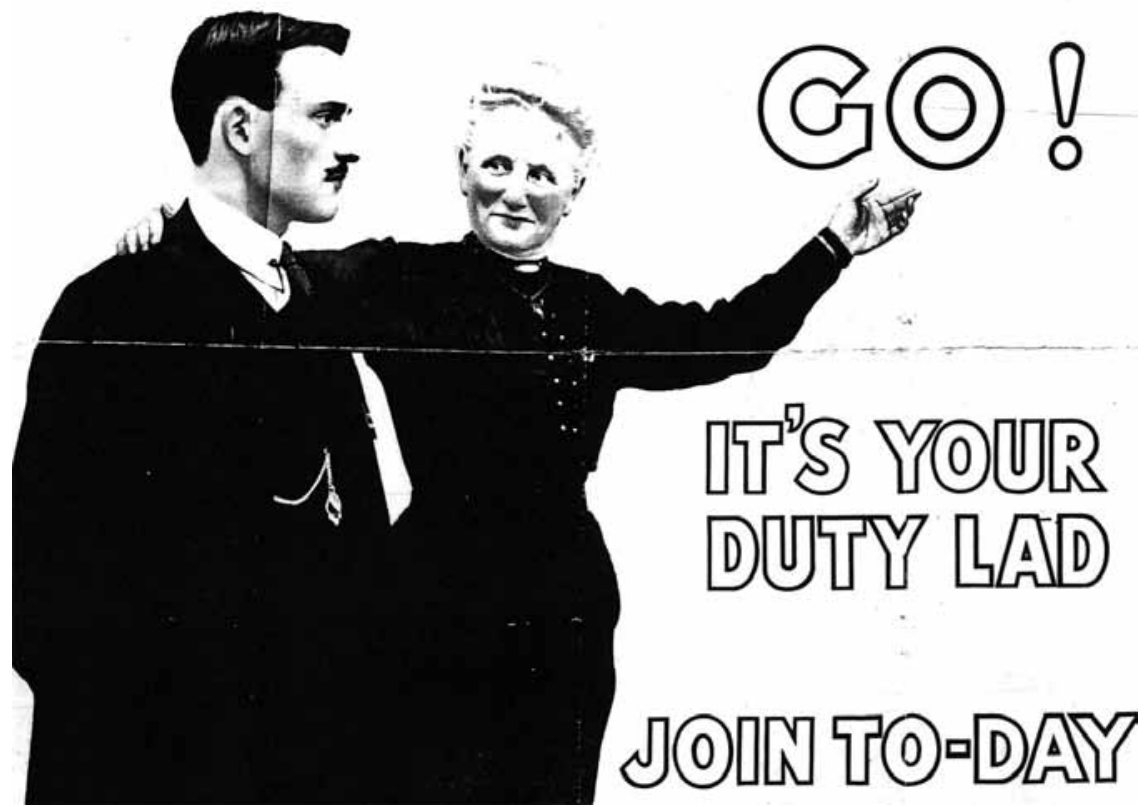

Fig. 1. - Propaganda's portrayal of the maternal injunction to join the army (IWM Q70864)

reads "Women of Britain Say-GO!" (275). A similar piece of propaganda with an even more commanding maternal overtone is the poster of the mother telling her son "Go-it's your duty lad" (see fig. 1). Her extended, pointing arm, recalling Kitchener's pointed declaration "your country needs you," lends the mother paternal authority, vesting the state with the immediate and uncontestable power of the mother, whose labor produces the raw material for war. The same trope was used for nursing recruitment posters, representing the mother as a hugely powerful and dominant figure, taking control of the male soldiers.

Importantly, this maternal labor produces material goods in the bodies of babies. Brittain's labor as a nurse is similarly concrete, mending damaged bodies generally so they can be returned to active service or cleared off the battlefield. Brittain always conceives herself when she is on active duty as nursing, by proxy, either her fiancé or her brother (166). Her transformation of every patient into Roland or Edward demonstrates an ambiguous desire both to be with these beloved men and to overcome or overpower them at the physical level. In her maternal role as nurse, Brittain is thus exercising a kind of control over both the men she loves and the perilous situation of the war by giving herself the clear tasks of daily re-creating the physical conditions necessary for the war. Like the figures in the propaganda posters, Brittain can loom above the soldiers, and so the war, thus trumping political consideration of the world with the fundamental act of re-creating its conditions (see fig. 2).

In subjecting herself to this self-effacing labor, Brittain ends up subjecting herself as much to the propaganda that encourages, and the rhetoric of the war that suggests, that "if a man cannot be useful to his country, he is better dead" 


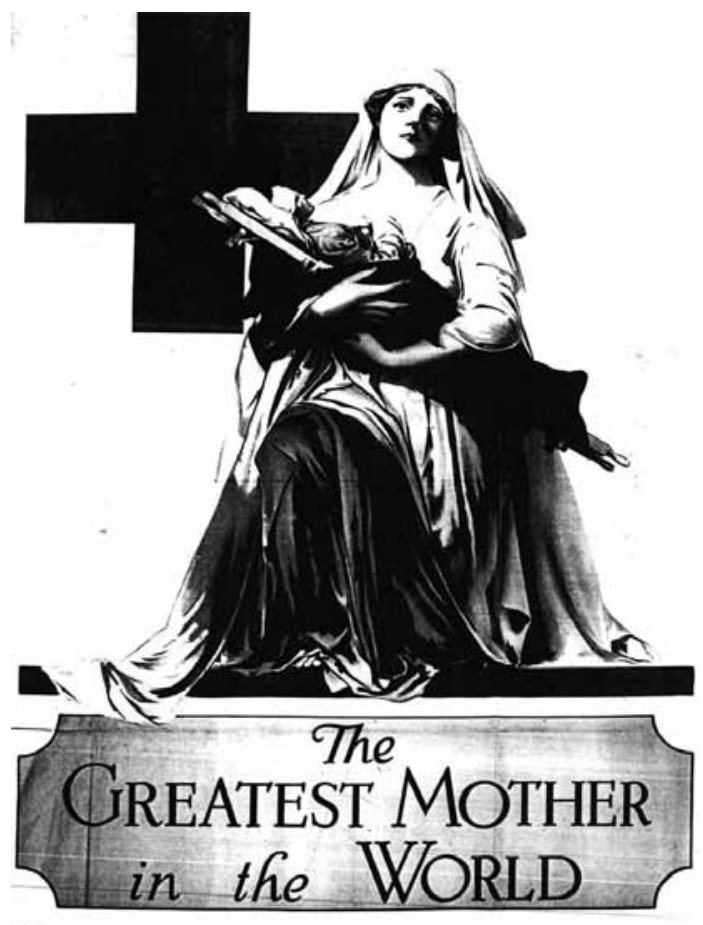

Fig. 2 - Nurse as gigantic mother (IWM Q79858)
(89). The extent to which this propaganda figures in Brittain's psychology cannot, of course, be precisely gauged, but it is remarkable that, after her close friend Victor (who had been, among Roland and Edward, one of the "Three Musketeers" of Uppingham Public School) is blinded, she almost immediately hatches a plan to marry him for the sake of sacrificing her future for a lifetime of the extended labor of being a war nurse.

The idea occurs to her when she learns one morning that another close friend, Geoffrey, has been killed. She remembers an advertisement she had cut out and sent to Roland two years earlier: "Lady, fiancé killed, will gladly marry officer totally blinded or otherwise incapacitated by the war." In

the letter, she had commented:

At first sight it is a little startling. Afterwards the tragedy of it dawn on you. The lady (probably more than a girl or she would have called herself 'young lady'; they always do) doubtless has no particular gift or qualification, and does not want to face the dreariness of an unoccupied and unattached old-maidenhood. But the only person she loved is dead; all men are alike to her and it is a matter of indifference whom she marries, so she thinks she may as well marry someone who really needs her. The man, she thinks, being blind or maimed for life, will not have much opportunity of falling in love with anyone, and even if he does will not be able to say so. But he will need a perpetual nurse, and she if married to him can do more for him than an ordinary nurse and will perhaps find relief from her sorrow in devoting her life to him. Hence the advertisement; I wonder if anyone will answer it? It is purely a business arrangement, with an element of self-sacrifice which redeems it from udder sordidness. Quite an idea, isn't it? (343-4)

Thus, she meant lovelessly to marry Victor partially, as she admits, to guard her mourning for Roland. But the self-negation implied in self-sacrifice also appeals to 


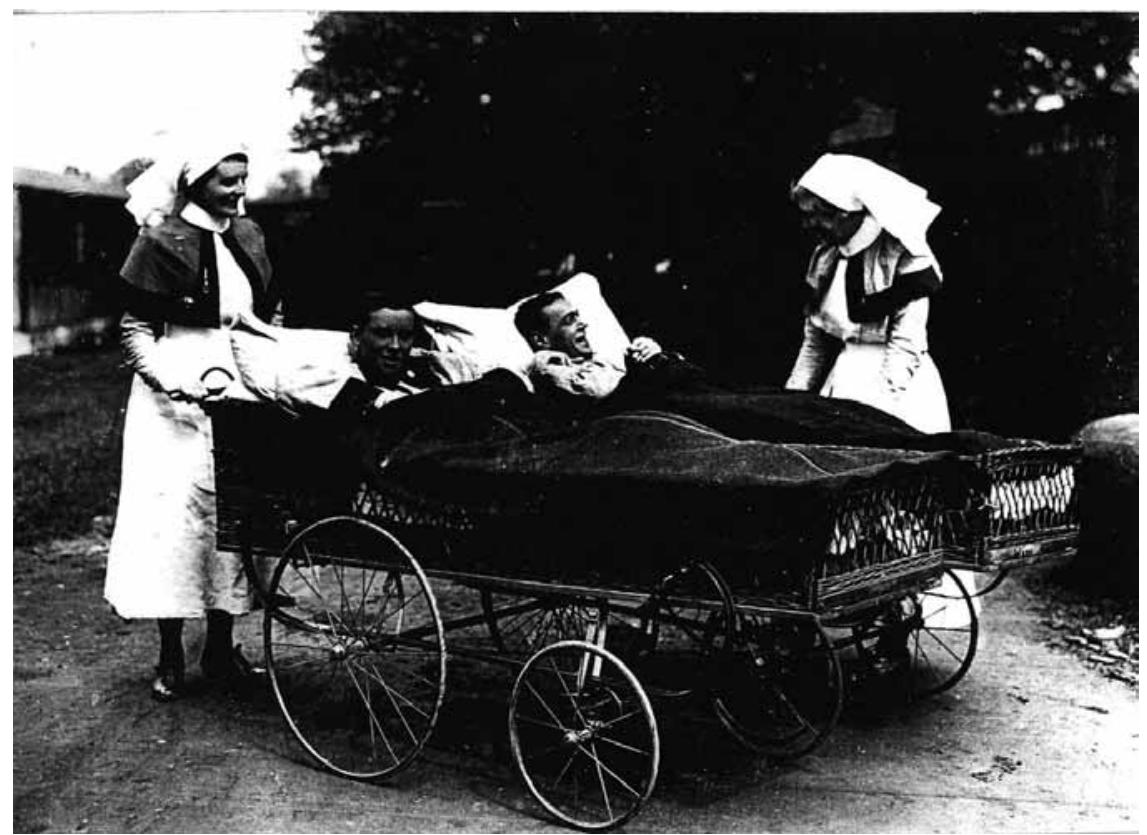

Fig. 3 - Nurses attending wounded soldiers in perambulators (IWM Q27814)

her. The life she envisions for such a wife-nurse is completely reduced to physical labor. It collapses the distinction between private, individual care of the body, and the body as a commodity to be sold on the market. Brittain realizes, in retrospect that Victor's death "probably saved [them] both from a relationship of which the serenity might have proved increasingly difficult to maintain" (359).

Tthe complete reversal of her characteristics, from the independent college student to the universal mother and thoughtless caregiver, demonstrates the extent to which the necessity of raw, difficult labor effaces the individuality constructed through the cultural activity of work. The control this world-preserving labor has given her is an illusion that depends on the self-erasure she had fought against in escaping provincial Buxton. Her value in nursing or in marrying Victor for the sake of prolonging her nursing labor indefinitely is only a function of her working body; it is not fundamentally a manifestation of her self. In the photo of two nurses attending soldiers in perambulators, the power structure is necessarily confusing. The nurses loom above the infantilized men, whose bodies, used by the war, are the sites of constant labor and ministration from the healthy bodies of the women, who both serve and control (see fig. 3).

As Brittain looks back to the period after Victor's death and her preparation for a third stint as a VAD, now headed for France where she will once again face imminent bodily danger, she reflects on the relation between her and her friends' constant renewal of commitments and propaganda: "Between 1914 and 1919," she writes "young men and women, disastrously pure in heart and unsuspicious of elderly self-interest and cynical exploitation, were continually re-dedicating 
themselves $[\ldots]$ to an end that they believed, and went on trying to believe, lofty and ideal" (370). What their rededication meant was a physical sacrifice to the state, a sacrifice that did not permit them to work constructively to contribute to their culture, nor to act and speak meaningfully to reshape the world. Indeed, the conditions of the nurse were much like the conditions of the soldier, and both were similar to the position of ideological impasse and imprisonment in which Brittain had been raised - one important difference being, however, that the demands of labor, of daily recreating the conditions of physical existence, obviated, mercifully, in Brittain's case, the possibility of thought. Throughout the war, though especially at its start, she "longed intensely for hard physical labour which would give [her] discomfort to endure and weariness to put mental speculation to sleep" (146).

\section{iii. Action and Internationalism}

Brittain's return to Oxford after the war constituted a time of trial and transformation in which, having lost her only friends to the war, she struggled to find meaning in the experiences that seemed of so little value to her classmates, who had been too young to experience it directly. But the war had propelled Brittain and her generation from the collectivity-based community structure that had made Edwardian life so uniform and enabled the mass physical sacrifice of labor for the war possible, to one based on the individual and individual needs.

The individuality Brittain had to fight so hard for the opportunity to forge is now taken for granted. It is encouraged in almost as insidious a way, it seems, as it had been denied before the war. This move from what had seemed like the "we-based" culture of her youth to the "me-based" postwar culture of her young adulthood presents Brittain with a dilemma: how will she use the individuality to which the state, in Foucault's terms, now addresses its power over the subject? Postwar, Brittain is set adrift from the tight control that her Edwardian youth and state service had enforced. In the atmosphere of that "thoroughly nasty Peace" (467) being waged in Paris, she observes "the hectic reactions of [her] generation, frantically dancing night after night $[\ldots]$ in the vain hope of recapturing the lost youth that the war had stolen" (468-9). To make up for their sacrifices, Brittain observes, other survivors of the war turned to the hedonistic pursuit of individual pleasures that the exhausted moral state of England now permitted and, through the agency of postwar culture, encouraged.

But Brittain has returned to Oxford under the internalized scrutiny of too many dead, measuring her actions against their lost lives, to enjoy the egotistical pleasures of individuality. She is admittedly, after four years of intentionally obliterating thought through the anodyne of labor, less than enthusiastic about returning to the thoughtful life and vegetative work of the student. The transition from labor back to work, as Brittain feared, was disastrous, for in finally having to think, she had to confront for the first time the utility and value of the deaths of her four close relations, the sacrifice of her youth, and the complete mental exhaustion that had left her in a state, essentially, of shell-shock.

While Brittain was undeniably, as Badenhausen and others have shown, suffering from posttraumatic stress disorder, her descriptions of her mental breakdown at 
Oxford revolve around a grief that is unresolved because it cannot attach significant use-value to its cause. In the months immediately following the war, when Brittain is able for the first time to think about the war in political terms, the conditions of the Treaty of Versailles seem to render the deaths of her relations and her own sacrificed years worthless:

These negotiations [...] did not seem to me to represent at all the kind of "victory" that the young men whom I had loved would have regarded as sufficient justification for their lost lives. Although they would no doubt have welcomed the idea of a League of Nations, Roland and Edward certainly had not died in order that Clemenceau should outwit Lloyd George, and both of them bamboozle President Wilson, and all three combine to make the beaten, blockaded enemy pay the cost of the War. For me the "Huns" were then, and always, the patient, stoical Germans whom I had nursed in France [...] So when the text of the Treaty of Versailles was published in May [...] I deliberately refrained from reading it; I was beginning already to suspect that my generation had been deceived, its young courage cynically exploited, its idealism betrayed, and I did not want to know the details of that betrayal. (470)

This immediately precedes Brittain explaining that she had decided to switch her subject at Oxford from English to History because "[a]fter the first dismayed sense of isolation in an alien peace-time world, such rationality as I still possessed reasserted itself in a desire to understand how the whole calamity had happened" (471).

The desire to understand the political past while ignoring the political future is a symptom of the melancholia that Badenhausen reads in Brittain's text. Reading her melancholia through Freud's 1917 delineation of "Mourning and Melancholia," Badenhausen interprets Brittain as unable to "take on another object of desire" because "she wishes to remain faithful to those who have died (423). These first few years of melancholic stasis back at school are chronicled in a chapter called "Survivors Not Wanted," which seethes with resentment at the lack of community and compassion Brittain confronted after her long ordeal. The students who have not shared her experience seem to partake still of an insular British world, which Brittain recognizes as feebly predicated on the assumption that larger historical and international political narratives cannot intervene. The incident that crystallizes Brittain's inevitable disillusionment comes when she is asked, by her then-nemesis Winifred Holtby, to take part in a debate, arguing that travel and experience are more valuable than a University education. Feeling that she and her own international experience are on trial, she is enraged and humiliated when the younger students, who were not involved in the war, make light of her sacrificial labor, arguing for the more culturally insular academic experience, which now seems to Brittain so much vegetative, masturbatory self-involvement.

Brittain represents this experience as traumatic because she felt isolated from those who had not experienced the labor, and its "exaltation" as she had. However, another hidden source of the trauma is the fear that her labor has been in vain. As 
she had set out to nurse by proxy the four men she cared about, and they all died, her labor yields no use value, and the lost years that she dedicated to physically demanding labor appear unredeemed. Her poem 'The Lament of the Demobilized," published in Oxford Poetry in 1920, makes this point trenchantly:

"You threw four years into the melting-pot-

Did you indeed!" these others cry. "Oh well,

The more fool you!"

And we're beginning to agree with them. (467)

The old faith in the war that had sustained her, even in her most disillusioned moments, cannot stand up to this new perception that the war has meant nothing for her culture but destruction. It has not changed the world, and the labor she put into it merely did, as Arendt suggests labor must, balance back out to zero at the end of the day.

The most remarkable manifestation of her trauma in these immediately postwar years, and the aspect of her story that has engendered the most scholarly work, also manifests itself in terms that uncannily mirror international politics. When confronted with the news of the death of yet another friend (from pneumonia) Brittain writes that she "flung [herself] furiously into [...] tennis parties, for I was sick beyond description of death and loss" (484), but this refusal to face loss and submit to becoming one of the Dionysian postwar revelers comes at a price: "I looked one evening into my bedroom glass and thought, with a sense of incommunicable horror, that I detected in my face the signs of some sinister and peculiar change. A dark shadow seemed to lie across my chin; was I beginning to grow a beard, like a witch?" (484). Thus begins a year of hallucinations in which Brittain is tormented by mirrors: "the horrible delusion [...] that my face was changing [...] became a permanent, fixed obsession" (496). The darkly ironic climax to this disorder comes when Brittain is assigned a room at Oxford that contains five enormous mirrors. The room was assigned to Brittain because the bursar "was amusedly aware of that vain interest in clothes" for which Brittain was good-naturedly teased by her classmates (499). The room is "invaded at night by armies of large, fat mice," and when Brittain has to enter the room, she writes, "I pressed my hands desperately against my eyes lest five identical witches' faces should suddenly stare at me from the cold, remorseless mirrors" (500).

Coming so soon after her disgusted reaction to the Treaty of Versailles, it is hard to miss the connection between Brittain's personal hall of mirrors, invaded by bellicose mice, and Versailles's Hall of Mirrors, invaded, as it was, by still bellicose statesmen intent on prolonging, rather than preventing, ongoing hostility. This personal hall of mirrors represents Brittain's failure to experience the Lacanian mirror stage moment in which one recognizes the (false) unity of the subject in her own body. Brittain's internal trauma is multiplied and reified by the geopolitical events in Versailles's hall of mirrors that her own experience recreates at the personal level. What in Versailles is meant to be an act of international unity becomes an act of further breakdown and fragmentation, implying that the breakdown of the "European Civil War" has made reunification impossible. Likewise, Brittain's 
inability to achieve subjective unity in her hall of mirrors indicates the level of traumatic personal breakdown that has caught up to her after her years of supposedly thoughtless labor. This confrontation with a multiplied self, the self that, looking out, sees only a hideous distortion of itself looking back, is the pinnacle of Brittain's traumatic isolation, and it compels Brittain to create community, to speak among and be recognized by others - she begins sleeping in Winifred Holtby's room, and as the two women start working for the League of Nations, Brittain is able to develop a new identity through action as a professional internationalist pacifist speaking at public lectures on behalf of the League of Nations.

Brittain's specific notion of internationalism shows an eagerness to escape the racially "species-preserving" control of biological life that the state had so explicitly propagandized as the point of the war. Her commitment to internationalism, so at odds with the frivolous youth and the hedonistic survivors that she describes, certainly owes something to her specific experiences as a nurse to both British and German soldiers. She has been in a unique position to see that the state power that asserts its control over the subject by guaranteeing "protection of the species" fulfills the same political functions, and for the same reasons, from state to state. Brittain cannot, however, transcend the racial insularity into which she was born and brought up, and her own ideological limitations correspond to those of the League of Nations in which she is so invested. She has made a leap to the realm of action, what Arendt describes as taking part in a larger community in which people speak and interact among each other to "reveal actively their unique personal identities" (179). In the arena of action presented by the League of Nations, Brittain can act in a communal and not merely self-interested or vegetative way. It presents an opportunity to be with others not, as in the provincial pre-war paradigm, in a prison of constant surveillance, but in the ultimately fulfilling if utopian sense of what Arendt describes as the possibility of people being "with others and neither for nor against them" (180), and which Agamben elaborates in his utopian vision of the coming community in which people can cultivate, finally, an unmediated being together.

Brittain's advocacy of the League of Nations is as utopian as Arendt's and Agamben's theories of new communities that overcome competition, but she also demonstrates that the utopian vision of the League of Nations is complicit with the national and racial prejudices it claims to transcend. In an armistice day address to "children between 10 and 14" on the theme of "Good Citizenship and the League," for instance, she wants to persuade the children that they must try to act as citizens of a world in which all nations are equal. She is also eager to point out, however, that this is a necessary result of the previous war, in which English men and women died to secure a world free from "the things that in 1914 Germany stood for, like overwhelming military despotism and the oppression of the weak" (6). Brittain is thus exemplary of the well-intentioned internationalists whose efforts were ultimately connected to the coming war they tried so hard to avert.

Brittain is limited by other racial and national ideologies of her time and place, as well. Julian Reid suggests that discourse can transcend the war that Foucault described as "just beneath the surface of peace" (qtd. in Reid 127) only by escaping the polemics that lead to war. Brittain's recounting of her cosmopolitan adventure 
ultimately reaffirms the "species-preserving" mandate of biopower, even while it demonizes that mandate's immediate national ends. Brittain is sympathetic to the Germans, but in her analysis of the occupation of the Ruhr, she devolves into the partisan anger that undermines the efforts of the League of Nations. Furthermore, Brittain is repulsed by the mid-Western Americans with whom she must share a train compartment, and her undisguised disgust at their presence in what she seems to feel has become, by virtue of internationalist sympathy, her Europe, demonstrates the extent to which her politics are based on experience, and the use-values she connects to the trial that Europe, and not the USA, has endured. Other reports about the international figures that she observes also reveal entrenched stereotypical notions. For instance, she tellingly describes the Japanese ambassadoras possessing the "solemn impassivity of the oriental demeanor," and concerned only with Japan - and this is at a time when Japan was practicing aggressive militarist colonialism in Korea, Taiwan and Manchuria (562).

Brittain may have resolved her trauma through finding an international community in which to take action, but that action, like the League of Nations itself, is still subject to the old polemics. Brittain's discourse ultimately reflects and partakes in these limitations. By occasionally undermining her own tentative resistance to the biopolitical structure of postwar England, Brittain's narrative confirms the essential irresistibility and inescapability of a power structure tried and strengthened in the same crucible as herself. Brittain's movement through work, labor and action, however, is ground-breaking and reflects a modern progression that could, perhaps, only have been possible as part of the cataclysm of war that proved to be the telos of English imperial culture.

\section{Notes}

1 Jed Esty describes the ethnographic and culturally insular turn of interwar modernism in A Shrinking Island (2003).

\section{Works Cited}

Agamben, Giorgio. State of Exception. Trans. Kevin Attell. Chicago: University of Chicago Press, 2005.

---. The Coming Community. Trans. Michael Hardt. Minneapolis: University of Minnesota Press, 1993.

Albrinck, Meg. "Borderline Women: Gender Confusion in Vera Brittain's and Evadne Price's War Narratives." Narrative 6.3 (1998): 271-91.

Arendt, Hannah. The Human Condition. Chicago: University of Chicago Press, 1958. Badenhausen, Richard. "Mourning through Memoir: Trauma, Testimony, and Community in Vera Brittain's Testament of Youth." Twentieth Century Literature 49.4 (2003): 421-48.

Brittain, Vera. Testament of Youth. New York: The MacMillan Company, 1933.

---. "Good Citizenship and the League." London: Pelican Press, 1924.

Esty, Jed. A Shrinking Island. Princeton: Princeton UP, 2003.

Ford, Ford Madox. England and the English. Ed. Sara Haslam. Manchester: Carcanet, 2003. 
---. Parade's End. New York: Penguin Books, 2001.

Foucault, Michel. Society Must Be Defended. Ed. Mauro Bertani and Alessandro Fontana. Trans. David Macey. New York: Picador, 1997.

---. Power: Essential Works of Foucault 1954-1984. Ed. James D. Faubion. Trans. Robert Hurley, et. al. New York: The New Press, 1994.

---. The History of Sexuality Volume III: The Care of the Self. Trans. Robert Hurley. New York: Vintage Books, 1986.

Fussell, Paul. The Great War and Modern Memory. Oxford: Oxford UP, 1975.

Leonardi, Susan J. "Brittain's Beard: Transsexual Panic in Testament of Youth." LIT: Literature, Interpretation, Theory 2.1 (1990): 77-84.

Reid, Julian. "Life Struggles: War, Discipline, and Biopolitics in the Thought of Michel Foucault." Social Text 8624.1 (2006): 127-152.

Stewart, Victoria. Women's Autobiography: War and Trauma. New York: Palgrave Macmillan, 2003. 
96 IJCS 